\title{
Human Plasma Protein C
}

\author{
ISOLATION, CHARACTERIZATION, AND MECHANISM \\ OF ACTIVATION BY $\alpha$-THROMBIN
}

\author{
WALTER KISIEL, Department of Biochemistry, University of Washington, \\ Seattle, Washington 98195
}

\begin{abstract}
A B S T RAC T Protein C is a vitamin K-dependent protein, which exists in bovine plasma as a precursor of a serine protease. In this study, protein $\mathrm{C}$ was isolated to homogeneity from human plasma by barium citrate adsorption and elution, ammonium sulfate fractionation, DEAE-Sephadex chromatography, dextran sulfate agarose chromatography, and preparative polyacrylamide gel electrophoresis. Human protein $\mathrm{C}\left(\boldsymbol{M}_{\mathrm{r}}\right.$ $=62,000$ ) contains $23 \%$ carbohydrate and is composed of a light chain $\left(M_{r}=21,000\right)$ and a heavy chain $\left(M_{r}\right.$ $=41,000$ ) held together by a disulfide bond(s). The light chain has an amino-terminal sequence of AlaAsn-Ser-Phe-Leu- and the heavy chain has an aminoterminal sequence of Asp-Pro-Glu-Asp-Gln. The residues that are identical to bovine protein $C$ are underlined. Incubation of human protein $\mathrm{C}$ with human $\alpha$-thrombin at an enzyme to substrate weight ratio of 1:50 resulted in the formation of activated protein $C$, an enzyme with serine amidase activity. In the activation reaction, the apparent molecular weight of the heavy chain decreased from 41,000 to 40,000 as determined by gel electrophoresis in the presence of sodium dodecyl sulfate. No apparent change in the molecular weight of the light chain was observed in the activation process. The heavy chain of human activated protein $\mathrm{C}$ also contains the active-site serine residue as evidenced by its ability to react with radiolabeled diisopropyl fluorophosphate. Human activated protein $\mathrm{C}$ markedly prolongs the kaolin-cephalin clotting time of human plasma, but not that of bovine plasma. The amidolytic and anticoagulant activities of human activated protein $C$ were completely obviated by prior incubation of the enzyme with diisopropyl fluorophosphate. These results indicate that human protein $C$,
\end{abstract}

\footnotetext{
A preliminary report of this work has appeared elsewhere (1). Dr. Kisiel is an Established Investigator of the American Heart Association.

Received for publication 2 April 1979 and in revised form 14 May 1979.
}

like its bovine counterpart, exists in plasma as a zymogen and is converted to a serine protease by limited proteolysis with attendant anticoagulant activity.

\section{INTRODUCTION}

Earlier work has demonstrated that protein $\mathrm{C}$ is a vitamin K-dependent glycoprotein, which exists in bovine plasma as a precursor of a serine protease $(2-4)$. Bovine protein $C$ is composed of a heavy chain $\left(M_{\mathrm{r}}=41,000\right)$ and a light chain $\left(M_{r}=21,000\right)$ held together by a disulfide bond(s). Incubation of bovine protein $C$ with either $\alpha$-thrombin or a protease from Russell's viper venom $(\mathrm{RVV}-\mathrm{X})^{1}$ resulted in the cleavage of an Arg-Ile peptide bond between residues 14 and 15 of the heavy chain with the concomitant activation of the zymogen. The heavy chain of activated protein $C$ contains the amino-terminal sequence of Ile-Val-Asp-Gly and an active-site sequence homologous with a number of plasma serine proteases (4).

Previous work from our laboratory has shown that bovine activated protein $C$ exhibits anticoagulant activity in the presence of phospholipid and calcium ions (5). From our present information, it appears highly probable that activated protein $\mathrm{C}$ is responsible for the anticoagulant activity described by Marciniak nearly a decade ago (6). Experiments employing homogeneous protein preparations indicate that the anticoagulant effect of activated protein $\mathrm{C}$ is caused in part by the inactivation of factor $\mathrm{V}_{\mathrm{a}} \cdot{ }^{2}$ This inactivation reaction involves the proteolytic cleavage of specific polypeptide chains in the factor $V_{a}$ molecule (8). The inactivation of factor $\mathrm{V}_{\mathrm{a}}$ by activated protein $\mathrm{C}$ requires phospholipid and calcium ions, and was inhibited by prior

${ }^{1}$ Abbreviations used in this paper: DFP, diisopropyl fluorophosphate; Mes, 2-( $N$-morpholino)ethanesulfonic acid; RVV-X, the protease from Russell's viper venom that activates factor $\mathrm{X}$; SDS, sodium dodecyl sulfate.

2 The nomenclature for the various clotting factors is that recommended by an international nomenclature committee (7). 
incubation of the enzyme with diisopropyl fluorophosphate (DFP) (8).

In this article, a procedure for the isolation of protein $\mathrm{C}$ from human plasma is presented along with some of the molecular properties of the purified protein. In addition, the mechanism of activation of human protein $\mathrm{C}$ by thrombin is described. This mechanism is essentially identical with that previously observed for bovine protein $C$ when it is activated by either trypsin $(3,4)$, RVV-X (4), or $\alpha$-thrombin (5).

\section{METHODS}

DEAE-Sephadex A-50, SP-Sephadex C-50, Sephadex G-150, Sephadex G-50, Sephadex G-15, Sepharose 4B and dextran sulfate were products of Pharmacia Fine Chemicals, Piscataway, N. J. Imidazole (Grade I), soybean trypsin inhibitor (type II-S), bovine serum albumin, ovalbumin, carbonic anhydrase, myoglobin, Coomassie Brilliant Blue R, dithiothreitol, lyophilized Vipera russelli venom, thiobarbituric acid, $N$-acetylneuraminic acid, factor II-deficient bovine plasma, factor $\mathrm{X}$-deficient bovine plasma, and Tris (Trizma) base were obtained from Sigma Chemical Co., St. Louis, Mo. Kaolin (acid washed) was purchased from Fisher Scientific Co., Fair Lawn, N. J. Factor IX- and factor VII-deficient human plasmas were obtained from George King Bio-Medical, Inc., Overland Park, Kans. Benzamidine hydrochloride, DFP, cyclohexanone, and 4-vinyl pyridine were purchased from Aldrich Chemical Co., Milwaukee, Wis. Ammonium sulfate (enzyme grade) and guanidine hydrochloride (ultrapure) were supplied by Schwarz/Mann Div. Becton, Dickinson \& Co., Orangeburg, N. Y., Sodium dodecyl sulfate (SDS) was obtained from British Drug House, Poole, England. Acrylamide, $N, N^{\prime}$-methylenebisacrylamide, $N, N, N^{\prime}, N^{\prime}$-tetramethylethylenediamine, and urea (electrophoresis grade) were purchased from Bio-Rad Laboratories, Richmond, Calif. Diisopropyl $N-\left[1-{ }^{3} \mathrm{H}\right]$ fluorophosphate $(0.9 \mathrm{Ci} / \mathrm{mmol})$ was obtained from New England Nuclear, Boston, Mass. Lithium heparin (150 USP U/mg) was obtained from Riker Laboratories, Inc., Northridge, Calif. D-phenylalanyl-L-pipecolyl-L-arginyl-p -nitroanilide (S-2238) was obtained from Ortho Diagnostics Inc., Raritan, N. J. Dansyl-arginine-4-ethyl piperidine amide was a generous gift of Dr. M. Nesheim, Mayo Clinic, Rochester, Minn. Sequenator reagents (Sequanal grade) were supplied by Pierce Chemical Co., Rockford, Il. Human antithrombin III was isolated by the method of Kurachi et al. (9) and was a gift from Dr. K. Kurachi, University of Washington. Bovine brain cephalin was prepared according to Bell and Alton (10). The venom RVV-X was purified as described (11). Human $\alpha$-thrombin was isolated essentially according to Lundblad et al. (12) after activation of human prothrombin by a factor $\mathrm{X}_{\mathrm{a}}-\mathrm{Ca}^{2+}$-phospholipid mixture (13). The specific activity of the thrombin preparation was 3,500 National Institutes of Health (NIH) U/mg protein. By SDS gel electrophoresis, this preparation appeared to contain $98 \% \alpha$-thrombin and $2 \% \beta$-thrombin.

Antibody against human factor $X$ was prepared from rabbits as described (14) and was kindly provided by Dr. R. DiScipio, University of Washington. Anti-human factor X-Sepharose was prepared by the overnight incubation of $100 \mathrm{mg}$ of rabbit anti-human factor $\mathrm{X}$ in $10 \mathrm{ml}$ of $0.1 \mathrm{M}$ sodium bicarbonate with $20 \mathrm{ml}$ of a Sepharose $4 \mathrm{~B}$ slurry previously activated with cyanogen bromide (15).

Protein C concentrations were determined from the absorbance at $280 \mathrm{~nm}$ using an $\mathrm{E}_{280}^{196}=14.5$ as estimated from its amino acid composition (16). An $E_{280}^{1.96}$ value of 18.3 was employed for determination of thrombin concentrations (17). For carbohydrate and amino-terminal sequence analyses, pro- tein content was determined by amino acid analyses after hydrolyzing an aliquot of the sample in $6 \mathrm{~N} \mathrm{HCl}$ for $24 \mathrm{~h}$ at $110^{\circ} \mathrm{C}$ in evacuated tubes.

SDS-polyacrylamide gel electrophoresis was performed as described (4) employing $10 \%$ polyacrylamide gels.

Amino acid analyses were carried out by standard procedures $(18,19)$ employing a Durrum model D500 amino acid analyzer (Durrum Instrument Corp., Sunnyvale, Calif.). Tryptophan was determined by the procedure of Hugli and Moore (20), and half-cystine was determined as cysteic acid according to Hirs (21).

Neuraminic acid was determined according to Warren (22). Hexose and hexosamine were determined after hydrolysis of the sample $(500-1,000 \mu \mathrm{g})$ in $90 \%$ glacial acetic acid containing $0.5 \mathrm{~N} \mathrm{H}_{2} \mathrm{SO}_{4}$ for $8 \mathrm{~h}$ at $80^{\circ} \mathrm{C}$ under a nitrogen atmosphere. Inositol was added to the sample to serve as an internal standard. After hydrolysis, the sugars were reduced and acetylated according to Yang and Hakomori (23). Sugars were identified and quantitated by gas chromatography and mass spectrometry employing a gas chromatograph (model 402; Hewlett-Packard Co., Palo Alto, Calif.) and a gas chromatograph-mass spectrometer (model 330; Finnigan Corp., Sunnyvale, Calif.). Glass columns $(6 \mathrm{ft} \times 1 / 8$ in) containing $3 \%$ OV-225 on Supelcoport were used (Supelco Inc., Bellefonte, Pa.). The columns were usually programmed for $10 \mathrm{~min}$ at $160^{\circ} \mathrm{C}$ followed by a $1^{\circ} \mathrm{C} / \mathrm{min}$ rise to $210^{\circ} \mathrm{C}$.

Automated Edman degradations were performed with a Beckman sequencer (model 890C; Beckman Instruments, Inc., Fullerton, Calif.) by a modification of the technique described by Edman and Begg (24). Dilute Quadrol (0.1 M; BASF Wyandotte Corp., Industrial Chemicals Group; Wyandotte, Mich.) was employed as the coupling buffer. Phenylthiohydantoin ( $\mathrm{Pth}$ ) amino acids were identified and quantitated by high pressure liquid chromatography $(25,26)$. For amino-terminal analyses, $\cong 3 \mathrm{mg}$ of the S-pyridylethylated heavy chain of protein $C$ and $2 \mathrm{mg}$ of the S-pyridylethylated light chain of protein $C$ were used. All analyses were performed in duplicate.

Amidase activity of activated protein $\mathrm{C}$ was measured as described (5) using Phe-Pip-Arg-p-nitroanilide (S-2238) as the chromogenic substrate.

Factor $\mathrm{X}$ and prothrombin were assayed by one-stage assays according to Bachmann et al. (27) and Hjort et al. (28), respectively. Factor IX was assayed according to Fujikawa et al. (29) and factor VII was assayed by the method of Nemerson and Clyne (30). All clotting assays were standardized with normal, pooled human plasma assuming $1 \mathrm{U}$ of clotting factor per milliliter plasma.

Protein $\mathrm{C}$ concentration in column and electrophoretic eluants was determined qualitatively by its ability to prolong the kaolin-cephalin clotting time of human plasma after activation by thrombin. Routinely, $100 \mu$ l of eluant was diluted in a plastic culture tube with $900 \mu \mathrm{l}$ of $0.1 \mathrm{M}$ Tris- $\mathrm{HCl}(\mathrm{pH}$ 8.0 ) containing $0.1 \%$ bovine serum albumin. $10 \mu \mathrm{g}$ of thrombin was then added and the mixture incubated at $37^{\circ} \mathrm{C}$ for $1 \mathrm{~h}$. At this time, $40 \mu \mathrm{g}$ of human antithrombin III and $40 \mu \mathrm{g}$ of heparin in $20 \mu \mathrm{l}$ of $50 \mathrm{mM}$ Tris- $\mathrm{HCl}(\mathrm{pH} 7.5)$ were added and the incubation was continued for an additional $15 \mathrm{~min}$ at $37^{\circ} \mathrm{C}$ to neutralize the thrombin. An aliquot of the incubation mixture was diluted 100 -fold with $50 \mathrm{mM}$ Tris- $\mathrm{HCl}$ ( $\mathrm{pH} 7.5)$ containing $100 \mathrm{mM} \mathrm{NaCl}$ and $0.1 \%$ bovine serum albumin before the kaolin-cephalin clotting assay. In this assay, $0.1 \mathrm{ml}$ of pooled, human plasma was incubated with $0.1 \mathrm{ml}$ solution of kaolin $(5 \mathrm{mg} / \mathrm{ml})$ in cephalin for $3 \mathrm{~min}$ at $37^{\circ} \mathrm{C}$ followed by the successive addition of $0.1 \mathrm{ml}$ of the test sample and $0.1 \mathrm{ml}$ of 0.025 $\mathrm{M} \mathrm{CaCl}_{2}$.

Dextran sulfate agarose was prepared by a modification of the method of Pepper and Prowse (31). $500 \mathrm{ml}$ (wet-packed) Sepharose 4B was suspended in an equal volume of distilled 
water. $20 \mathrm{~g}$ of dextran sulfate was then added and the $\mathrm{pH}$ adjusted to 11 with $6 \mathrm{M} \mathrm{NaOH} .100 \mathrm{ml}$ of acetonitrile containing $100 \mathrm{~g}$ of cyanogen bromide was then added and coupling was performed for $45 \mathrm{~min}$. Throughout the coupling stage, the $\mathrm{pH}$ was maintained at 11 with $6 \mathrm{M} \mathrm{NaOH}$ and the temperature was maintained between $4^{\circ}$ and $10^{\circ} \mathrm{C}$ by the addition of ice chips. After coupling, the dextran sulfate agarose was filtered and resuspended in 2 liters of $1 \mathrm{M}$ glycine ethyl ester ( $\mathrm{pH} \mathrm{9.0)}$ and stirred at room temperature for $15 \mathrm{~h}$. The dextran sulfate agarose was then washed exhaustively with 1 $\mathrm{M} \mathrm{NaCl}$ and resuspended in $0.02 \mathrm{M} 2-(N$-morpholino $)$ ethanesulfonic acid (Mes)-Tris ( $\mathrm{pH}$ 6.0) containing $1 \mathrm{mM}$ benzamidine $\mathrm{HCl}, 2.5 \mathrm{mM} \mathrm{CaCl}_{2}$, and $0.02 \% \mathrm{NaN}_{3}$.

The heavy and light chains of human protein $\mathrm{C}$ were prepared as follows. Protein $\mathrm{C}(8-10 \mathrm{mg})$ was reduced and S-pyridylethylated according to Friedman et al. (32). Salts and excess reagents were removed by gel filtration in a Sephadex G-50 column $(2.6 \times 65 \mathrm{~cm})$ previously equilibrated with 2.3 $M$ formic acid. The heavy and light chains were separated by gel filtration in a Sephadex G-150 column $(1.6 \times 95 \mathrm{~cm})$ previously equilibrated with $2.3 \mathrm{M}$ formic acid containing $3 \mathrm{M}$ urea. Salt-free protein was obtained by gel filtration in Sephadex G-15 columns equilibrated with $1.2 \mathrm{M}$ formic acid followed by lyophilization. The heavy and light chains of human activated protein $C$ were prepared in an identical manner. In this experiment, $3 \mathrm{mg}$ of activated protein $\mathrm{C}$ was treated with $50 \mu \mathrm{Ci}$ of tritiated DFP before reduction and alkylation.

Purification of human protein $C$. All steps in the purification procedure were performed at $4^{\circ} \mathrm{C}$. Heparin $(30,000$ USP $\mathrm{U})$, soybean trypsin inhibitor $(500 \mathrm{mg}), 3 \mathrm{ml} 1 \mathrm{M} \mathrm{O}$-phenanthroline, and $1.5 \mathrm{ml}$ of $1 \mathrm{M}$ DFP were added to 15 liters of human citrated cryosupernate and the mixture was stirred for $15 \mathrm{~min}$. $600 \mathrm{ml}$ of $1 \mathrm{M} \mathrm{BaCl}_{2}$ was then added and the mixture stirred for an additional $30 \mathrm{~min}$. The barium citrate pellet was washed twice $(1 \mathrm{~h} /$ wash) with 3 liters of $0.02 \mathrm{M}$ imidazole- $\mathrm{HCl}(\mathrm{pH}$ 6.0) containing $0.3 \mathrm{M} \mathrm{NaCl}$ and $5 \mathrm{mM}$ benzamidine. Protein was eluted from the barium citrate pellet by stirring for $1-2 \mathrm{~h}$ in 2 liters of $0.2 \mathrm{M} \mathrm{Mes}-\mathrm{HCl} / 0.15 \mathrm{M}$ sodium citrate $(\mathrm{pH} \mathrm{6.0})$ containing $20 \mathrm{mM}$ benzamidine and $1 \mathrm{mM} O$-phenanthroline. The precipitate was removed by centrifugation at $5,000 \mathrm{~g}$ for $30 \mathrm{~min}$.

The supernate was brought to $35 \%$ saturation with ammonium sulfate by the slow addition of the salt. The mixture was stirred for $1 \mathrm{~h}$ and the precipitate was removed by centrifugation and discarded. The supernate was then adjusted to $65 \%$ saturation with ammonium sulfate by the slow addition of the salt. The precipitate was collected by centrifugation at $5,000 \mathrm{~g}$ for $30 \mathrm{~min}$ and dissolved in $150 \mathrm{ml}$ of $20 \mathrm{mM}$ Tris- $\mathrm{H}_{3} \mathrm{PO}_{4}(\mathrm{pH} 6.0$ ) containing $10 \mathrm{mM}$ benzamidine and 1 $\mathrm{mM}$ DFP. The protein solution was then dialyzed against 4 liters of this buffer for $15 \mathrm{~h}$. A fine precipitate that developed during dialysis was removed by centrifugation at $18,000 \mathrm{~g}$ for $10 \mathrm{~min}$.

The protein solution was applied to a DEAE-Sephadex A-50 column $(2.6 \times 70 \mathrm{~cm})$ previously equilibrated with 20 $\mathrm{mM}$ Tris- $\mathrm{H}_{3} \mathrm{PO}_{4} / 2 \mathrm{mM}$ benzamidine ( $\mathrm{pH} \mathrm{6.0)}$ ). The column was then washed with $200 \mathrm{ml}$ of equilibrating buffer containing $0.15 \mathrm{M} \mathrm{NaCl}$. The proteins were then eluted from the column with a linear gradient of $\mathrm{NaCl}$ generated from $325 \mathrm{ml}$ of $20 \mathrm{mM}$ Tris- $\mathrm{H}_{3} \mathrm{PO}_{4} / 0.15 \mathrm{M} \mathrm{NaCl} / 2 \mathrm{mM}$ benzamidine $(\mathrm{pH}$ 6.0 ) and $325 \mathrm{ml}$ of $20 \mathrm{mM}$ Tris- $\mathrm{H}_{3} \mathrm{PO}_{4} / 0.6 \mathrm{M} \mathrm{NaCl} / 2 \mathrm{mM}$ benzamidine ( $\mathrm{pH}$ 6.0). The flow rate was $30 \mathrm{ml} / \mathrm{h}$ and fractions of $3 \mathrm{ml}$ were collected in plastic tubes. The fractions containing protein $C$ activity were pooled, made $1 \mathrm{mM}$ in DFP, and $5 \mathrm{mM}$ in EDTA, and dialyzed against 4 liters of $20 \mathrm{mM}$ Mes-Tris/ $1 \mathrm{mM}$ benzamidine (pH 6.0) for $15 \mathrm{~h}$.

After dialysis, the solution was made $2.5 \mathrm{mM}$ in $\mathrm{CaCl}_{2}$ and applied to a dextran sulfate agarose column $(1.6 \times 35 \mathrm{~cm})$ previously equilibrated with $20 \mathrm{mM}$ Mes-Tris/2.5 mM CaCl $2 / 1$
$\mathrm{mM}$ benzamidine ( $\mathrm{pH}$ 6.0). After sample application, the column was washed with $150 \mathrm{ml}$ of equilibrating buffer. Protein $\mathrm{C}$ was then eluted from the column with a linear gradient of $\mathrm{NaCl}$ formed by $150 \mathrm{ml}$ of equilibrating buffer and $150 \mathrm{ml}$ of equilibrating buffer containing $1 \mathrm{M} \mathrm{NaCl}$. The flow rate was maintained with a peristaltic pump at $1 \mathrm{ml} / \mathrm{min}$ and $2-\mathrm{ml}$ fractions were collected. Protein $\mathrm{C}$ obtained from this column was free of factor IX but contained trace amounts of factor $\mathrm{X}$ and appreciable amounts of prothrombin and protein $S$.

The fractions from the dextran sulfate agarose column containing protein $\mathrm{C}$ were pooled and brought to $5 \mathrm{mM}$ DFP and $10 \mathrm{mM}$ EDTA. The pooled sample was concentrated to $\cong 10 \mathrm{ml}$ by ultrafiltration (PM 10 membrane) and dialyzed against 4 liters of $50 \mathrm{mM}$ Tris-boric acid $/ 10 \mathrm{mM}$ benzamidine $/ 5$ mM EDTA ( $\mathrm{pH} 8.0$ ) for $15 \mathrm{~h}$. The dialyzed sample was subjected to preparative discontinuous electrophoresis at $0^{\circ}-2^{\circ} \mathrm{C}$ in a Buchler Poly-Prep 200 apparatus (Buchler Instruments Div. Searle Diagnostics Inc., Fort Lee, N. J.) as described (4). Under these electrophoretic conditions, protein $\mathrm{C}$ elutes before prothrombin and protein S. Protein $\mathrm{C}$ obtained from preparative electrophoresis was completely free of factor VII, factor IX, and prothrombin activity when $100 \mu \mathrm{g}$ (in $100 \mu \mathrm{l}$ ) was assayed in each specific clotting assay. Occasionally, significant amounts of factor $\mathrm{X}$ activity were observed in purified preparations of protein $C$. Factor $X$ was completely removed from these preparations by passing the sample through a column $(1.6 \times 5 \mathrm{~cm})$ of rabbit anti-human factor $X$ agarose. The purified preparations of protein $C$ were routinely made $10 \mathrm{mM}$ in DFP, concentrated by ultrafiltration to about 1 $\mathrm{mg} / \mathrm{ml}$, and stored at $-80^{\circ} \mathrm{C}$. For characterization and activation studies, protein $\mathrm{C}$ was freed of inhibitor and salts on a column of Sephadex G-15 equilibrated with the appropriate buffer or solvent.

\section{RESULTS}

Preparation of human protein $C$. Protein $\mathrm{C}$ was isolated from human plasma by a five-step procedure, which included barium citrate adsorption and elution, ammonium sulfate fractionation, DEAE-Sephadex chromatography, dextran sulfate agarose chromatography, and preparative polyacrylamide gel electrophoresis. Approximately $5 \mathrm{mg}$ of purified protein was routinely obtained from 15 liters of plasma.

During the purification procedure, protein $\mathrm{C}$ concentrations were determined qualitatively after its activation by thrombin in an assay based upon the ability of activated protein $\mathrm{C}$ to prolong the kaolin-cephalin clotting time of human plasma. Despite the fact that antibody against human protein $C$ could readily be raised in rabbits, attempts to quantitate human protein $\mathrm{C}$ by immunochemical procedures similar to those employed for bovine protein $\mathrm{C}(2)$ proved unsuccessful. In this study, the use of the immunochemical assay was precluded by the low plasma concentration of human protein $\mathrm{C}$, which resulted in rockets of insufficient size for reliable measurements. The possibility of increasing the sensitivity of the immunochemical assay for human protein $\mathrm{C}$ in plasma using ${ }^{125} \mathrm{I}$-labeled antibodies is presently under investigation in this laboratory. Accordingly, quantitative data in terms of recovery and fold purification of protein $\mathrm{C}$ from human plasma in this study are presently not available. 


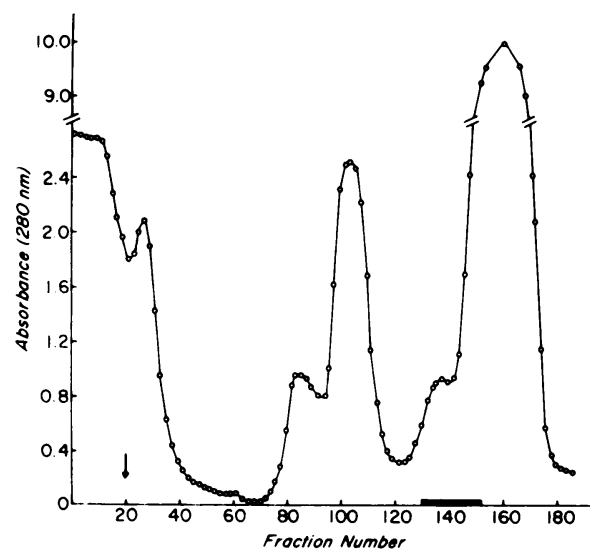

FIGURE 1 Elution pattern of human protein $C$ from DEAESephadex. Protein was eluted from the column $(2.6 \times 70 \mathrm{~cm})$ with a linear gradient of $325 \mathrm{ml}$ of $20 \mathrm{mM}$ Tris- $\mathrm{H}_{3} \mathrm{PO}_{4}(\mathrm{pH} 6.0)$ containing $0.15 \mathrm{M} \mathrm{NaCl}$ and $325 \mathrm{ml}$ of $20 \mathrm{mM}$ Tris- $\mathrm{H}_{3} \mathrm{PO}_{4}$ (pH 6.0) containing $0.6 \mathrm{M} \mathrm{NaCl}$. Fractions $(3 \mathrm{ml}$ ) were collected at a flow rate of $30 \mathrm{ml} / \mathrm{h}$. Fractions that were pooled are indicated by the bar. The arrow indicates initiation of the gradient.

In the isolation procedure, protein $\mathrm{C}$ was partially resolved from prothrombin, factor IX, factor $\mathrm{X}$, and protein $S$ by DEAE-Sephadex column chromatography (Fig. 1). Factor VII activity appeared in fractions 110 120 and was well separated from protein C. Protein C was further purified by dextran sulfate agarose column chromatography (Fig. 2). Protein C obtained from dextran sulfate agarose chromatography contained $\cong 50 \%$ prothrombin and protein $S$ as judged by SDS gel electrophoresis. In addition, small amounts of factor $\mathrm{X}$ activity were observed in these preparations.

Protein C was completely resolved from prothrombin and protein $S$ by preparative polyacrylamide disc gel

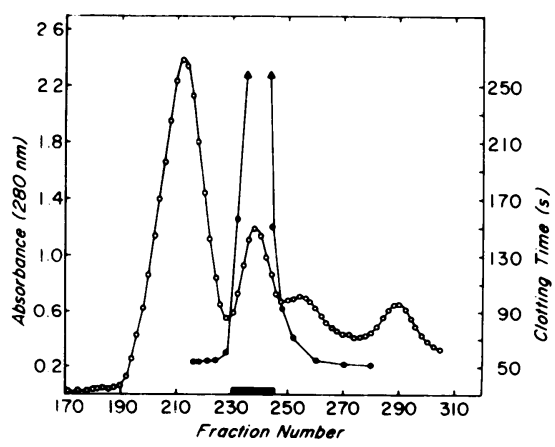

Figurf 2 Elution pattern of human protein C from dextran sulfate agarose. Protein was eluted from the column $(1.6 \times 35$ $\mathrm{cm}$ ) with a linear gradient of $150 \mathrm{ml}$ of $20 \mathrm{mM}$ Mes-Tris $/ 2.5 \mathrm{mM}$ $\mathrm{CaCl}_{2} / 1 \mathrm{mM}$ benzamidine $(\mathrm{pH} 6.0)$ and $150 \mathrm{ml}$ of $20 \mathrm{mM}$ Mes-Tris/l $\mathrm{M} \mathrm{NaCl} / 2.5 \mathrm{mM} \quad \mathrm{CaCl}_{2} / 1 \mathrm{mM}$ benzamidine $(\mathrm{pH}$ 6.0). Fractions $(2 \mathrm{ml})$ were collected at a flow rate of $1 \mathrm{ml} / \mathrm{min}$. Fractions that were pooled are indicated by the bar. (○), absorbance at $280 \mathrm{~nm}$; (๑), kaolin-cephalin clotting time.

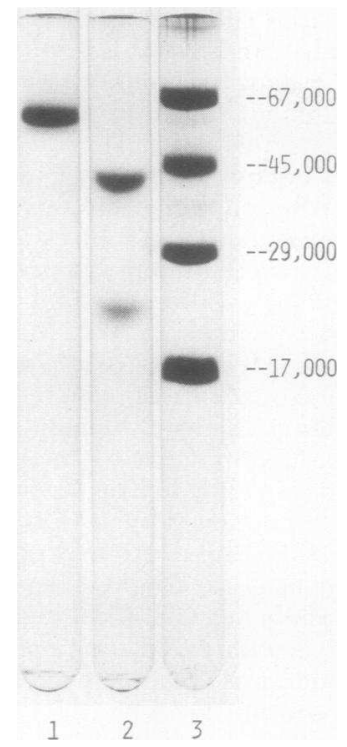

FIGURE 3 SDS-polyacrylamide gel electrophoresis of human protein C. Sample 1, $20 \mu \mathrm{g}$ unreduced protein C; sample 2 , $20 \mu \mathrm{g}$ of reduced protein $\mathrm{C}$; sample 3 contains a mixture of reduced standard proteins, which include bovine serum albumin $(67,000)$, ovalbumin $(45,000)$, carbonic anhydrase $(29,000)$ and myoglobin $(17,000)$. Electrophoresis was carried out as described in Methods.

electrophoresis. Protein $\mathrm{C}$ obtained from preparative electrophoresis often contained trace amounts of factor $\mathrm{X}$, which was readily removed by passing the sample through a small column of anti-human factor $\mathrm{X}$-agarose. The recovery of protein $\mathrm{C}$ in the preparative electrophoresis step was greatly improved by prior equilibration of the protein sample with EDTA-containing buffers. For reasons not fully understood, human protein $\mathrm{C}$ apparently forms molecular aggregates during the concentrating (stacking) process in discontinuous electrophoresis. These aggregates possess considerably lower electrophoretic mobilities and require inordinately long times to elute from the preparative gel. In most instances, treatment of the protein $C$ sample obtained from dextran sulfate agarose chromatography with EDTA before electrophoresis greatly reduced the aggregation suggesting that this phenomenon was in part calcium-dependent.

Molecular weight of human protein $C$ by SDSpolyacrylamide gel electrophoresis. A single protein band was observed by SDS-polyacrylamide gel electrophoresis for human protein $\mathrm{C}$ (Fig. 3, sample 1 ) and a mol wt of 62,000 was estimated by this technique for the unreduced protein. After reduction with 2 -mercaptoethanol, a heavy chain $\left(M_{\mathrm{r}}=41,000\right)$ and a light chain $\left(M_{\mathrm{r}}=21,000\right)$ were observed (Fig. 3, sample 2). Several purified preparations of human protein $C$ appeared as a broad, single band for the unreduced protein which upon reduction 
yielded a minor band $\left(M_{\mathrm{r}}=38,000\right)$ between the heavy and light chains. A number of attempts to remove this contaminant by ion-exchange chromatography and electrophoresis proved unsuccessful. Subsequent activation studies revealed that this species in all probability represented a proteolytic degradation product of the heavy chain of protein $\mathrm{C}$ similar to that observed for bovine and human factor $\mathrm{X}(14,33,34)$. The step(s) in the isolation procedure where this degradation occurs is presently unknown. The degradation product is observed by SDS gel electrophoresis in protein C samples obtained from DEAE-Sephadex chromatography. The relative amount of this species, tentatively identified as $\beta$-protein $C$, remained constant through the isolation steps after DEAE-Sephadex. Thus, it would appear that despite the liberal use of protease inhibitors, the formation of $\beta$-protein $\mathrm{C}$ occurs early in the isolation procedure and conceivably could be present in the starting plasma.

Amino acid and carbohydrate compositions of human protein $C$. The amino acid and carbohydrate compositions of human protein $\mathrm{C}$ are presented in Table I together with the composition of bovine protein C. From these data, human and bovine protein C appear remarkably similar in composition with the notable exceptions of their histidine, valine, and $\mathrm{N}$-acetylglucosamine contents. In addition, DiScipio and Davie (35) recently have reported that human and bovine protein $\mathrm{C}$ each contain 10 residues of $\gamma$-carboxyglutamic acid per mole of protein. Human protein $\mathrm{C}$ appears to be more highly glycosylated than the bovine protein and contains $\cong 23 \%$ carbohydrate including mannose, galactose, glucosamine, and neuraminic acid. Thus, human protein $\mathrm{C}$ is composed of about $14,300 \mathrm{~g}$ of carbohydrate and $47,000 \mathrm{~g}$ of protein $/ 62,000 \mathrm{~g}$ of glycoprotein.

Amino-terminal sequence. Amino-terminal analyses of the S-pyridylethylated heavy and light chains of human protein $\mathrm{C}$ were carried out in a Beckman sequencer. Aspartic acid was identified as the aminoterminal residue in the heavy chain and no other amino acids were detected. This is the same residue found in the amino-terminus of the heavy chain of bovine protein C. Despite this similarity, the next 17 aminoterminal residues of the heavy chain were completely different from that observed in the heavy chain of bovine protein C. Furthermore, this sequence is not homologous with the amino-terminal sequence of the heavy chains of either bovine or human factor X (34). The amino-terminal sequence of the first 18 residues of the heavy chain of human protein $\mathrm{C}$ and the equivalents per $41,000 \mathrm{~g}$ of protein were as follows: Asp (0.8), Pro (0.3), Glu (0.6), Asp (0.3), Gln (0.4), Glu (0.4), Asp (0.2), Gln (0.3), Val (0.4), Asp (0.3), Pro (0.2), Arg (0.1), Leu (0.3), Ile (0.2), Asp (0.1), Gly (0.1), Lys (0.1), and Val $(0.2)$. The repetitive yields for the degradations were
TABLE I

Comparison of the Amino Acid and Carbohydrate Compositions of Human and Bovine Plasma Protein $C^{*}$

\begin{tabular}{|c|c|c|}
\hline Components & Human $\downarrow$ & Bovine $\S$ \\
\hline \multicolumn{3}{|l|}{ Amino acid } \\
\hline Lysine & 22.1 & 24.9 \\
\hline Histidine & 16.6 & 10.6 \\
\hline Arginine & 22.2 & 29.1 \\
\hline Aspartic acid & 41.2 & 42.4 \\
\hline Threonine & 18.2 & 19.9 \\
\hline Serine & 31.5 & 27.6 \\
\hline Glutamic acid & 51.1 & 56.8 \\
\hline Proline & 19.5 & 20.1 \\
\hline Glycine & 35.9 & 42.3 \\
\hline Alanine & 22.2 & 21.7 \\
\hline Half-cystine ${ }^{\|}$ & 23.6 & 20.7 \\
\hline Valine & 24.5 & 32.3 \\
\hline Methionine & 5.9 & 7.7 \\
\hline Isoleucine & 15.5 & 17.2 \\
\hline Leucine & 40.3 & 36.9 \\
\hline Tyrosine & 7.1 & 9.9 \\
\hline Phenylalanine & 13.7 & 16.1 \\
\hline Tryptophan 9 & 13.8 & 14.5 \\
\hline \multicolumn{3}{|l|}{ Carbohydrate } \\
\hline Galactose & 14.4 & \\
\hline Mannose & 21.0 & $28.9^{* *}$ \\
\hline$N$-Acetylglucosamine & 23.4 & 9.7 \\
\hline$N$-Acetylneuraminic acid & 11.9 & 14.0 \\
\hline Protein, \% & 77 & 82 \\
\hline Carbohydrate, \% & 23 & 18 \\
\hline
\end{tabular}

* Compositions expressed as residues $/ 62,000 \mathrm{~g}$ glycoprotein. $\ddagger$ This study.

\$ Data taken from Kisiel et al. (4).

"Determined as cysteic acid according to Hirs (21).

I Determined by the method of Hugli and Moore (20).

** Total neutral hexose.

$>95 \%$. The amino acid sequence for the light chain was also determined and the equivalents per $21,000 \mathrm{~g}$ of protein were as follows: Ala (0.9), Asn (0.6), Ser (0.2), Phe (0.9), Leu (0.9), Gla (not quantitated), Gla (not quantitated), Leu (0.4), Arg (0.2), Ile (0.3), Ser, Trp, Lys and Gla. The last four residues were not quantitated. No Pth-amino acids were detected in positions 6 and 7 in the light chain. It appears highly probable, however, that $\gamma$-carboxyglutamic acid occupies these two positions because this amino acid has been identified in in these positions in the light chain of bovine protein $\mathrm{C}$. Thus, the first nine residues of the light chain of human protein $\mathrm{C}$ are identical to that found in the light chain of bovine protein C. Pth-glutamic acid was the major derivative observed in position 14 . This residue in all likelihood is also $\gamma$-carboxyglutamic acid because it occurs in position 14 in the bovine protein (36). The Pth-glutamic acid observed in position 14 conceivably 


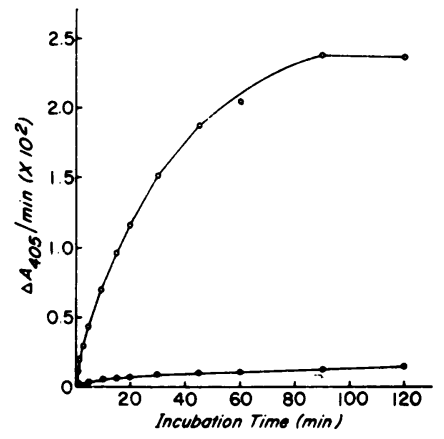

FIGURE 4 Time-course for the activation of human protein $\mathrm{C}$ by human $\alpha$-thrombin. The activation by thrombin was performed by adding thrombin $(40 \mu \mathrm{g})$ to a reaction mixture containing $2.3 \mathrm{mg}$ of human protein $\mathrm{C}$ in $10 \mathrm{ml}$ of $20 \mathrm{mM}$ Tris$\mathrm{HCl}(\mathrm{pH} \mathrm{8.0)}$. At the appropriate time intervals, aliquots $(100 \mu \mathrm{l})$ were withdrawn and transferred to a test tube containing $10 \mu \mathrm{g}$ of human antithrombin III and $10 \mu \mathrm{g}$ heparin in $3 \mu \mathrm{l}$ of $50 \mathrm{mM}$ Tris- $\mathrm{HCl}(\mathrm{pH} \mathrm{7.5)}$. Amidase activity was measured as described in Methods (O), complete reaction mixture; (๑), DFP-treated samples.

could arise from the acid-catalyzed decarboxylation of $\gamma$-carboxyglutamic acid during the first 13 steps in the Edman degradation. Accordingly, this residue is also tentatively identified as Gla.

Activation of human protein $C$ by thrombin. Incubation of human protein $\mathrm{C}$ with human $\alpha$-thrombin at an enzyme to substrate weight ratio of 1:50 resulted in the conversion of protein $\mathrm{C}$ to activated protein $\mathrm{C}$. A time-course for the activation of human protein $\mathrm{C}$ is shown in Fig. 4. The activation was monitored by determining the amidase activity toward D-Phe-PipArg- $p$-nitroanilide in aliquots of the reaction mixture removed at various time intervals. The activation process was terminated in these aliquots by the addition of human antithrombin III and heparin. An alternative method for terminating the activation reaction used the addition of dansyl-arginine-4-ethyl-piperidine amide to each aliquot ( $0.1 \mathrm{mM}$ final concentration). This compound has recently been shown to be a highly specific, potent inhibitor of thrombin (37). In control experiments, it was observed that neither dansylarginine-4-ethyl-piperidine amide nor antithrombin III in the presence of heparin had any appreciable effect on the amidase activity of human activated protein $\mathrm{C}$, while thrombin activity was completely inhibited. A portion of each aliquot was then made $5 \mathrm{mM}$ in DFP and the remainder of each aliquot was treated with isopropanol to serve as a control. As shown in Fig. 4, amidase activity reached a maximum in $\cong 90 \mathrm{~min}$ (open circles) and DFP treatment strongly inhibited this activity (solid circles). The experiments with DFP indicated that the amidase formed in this activation reaction in a serine amidase. A similar time curve (data not shown) was observed for reaction mixtures of human protein $\mathrm{C}$ and $\mathrm{RVV}-\mathrm{X}$ at $\mathrm{pH} 8$ and $37^{\circ} \mathrm{C}$ in the presence of $5 \mathrm{mM}$ calcium chloride. In these experiments, however, the activation reaction proceeded at a considerably lower rate and required $\cong 3 \mathrm{~h}$ to go to completion when protein $\mathrm{C}$ was incubated with RVV-X at a 1:50 enzyme to substrate weight ratio.

Evidence for a change in the molecular weight of human protein $\mathrm{C}$ during its activation by thrombin was shown by SDS gel electrophoresis after reduction with 2-mercaptoethanol (Fig. 5). The starting material showed two major bands corresponding to the heavy and light chains as well as a minor band $\left(M_{\mathrm{r}}=38,000\right)$ presumed to be a degradation product of the heavy chain. The band $\left(M_{r}=33,000\right)$ above the light chain of human protein $C$ represents the heavy chain of the added thrombin. After the addition of thrombin, a reduction in the molecular weight of the heavy chain of human protein $C$ from 41,000 to 40,000 was observed. Although not readily discernible in Fig. 5, the molecular weight of the heavy chain of $\beta$-protein $C$ decreased from 38,000 to 36,500 and this reaction coincided with the cleavage of the parent heavy chain. The simultaneous decrease in the molecular weight of both heavy chains provided evidence that the $M_{\mathrm{r}}=38,000$ polypeptide observed in purified preparations of human protein $\mathrm{C}$ was a proteolytic degradation product of the heavy chain. Furthermore, it is highly probable that the difference between the two forms of the heavy chain of human protein $\mathrm{C}$ is not a result of heterogeneity at the amino-terminal portion of the polypeptide (Discussion). No apparent change in the molecular weight of the light chain was observed during the activation reaction. Thus, these experiments demonstrated that the activation of human protein $\mathrm{C}$ by

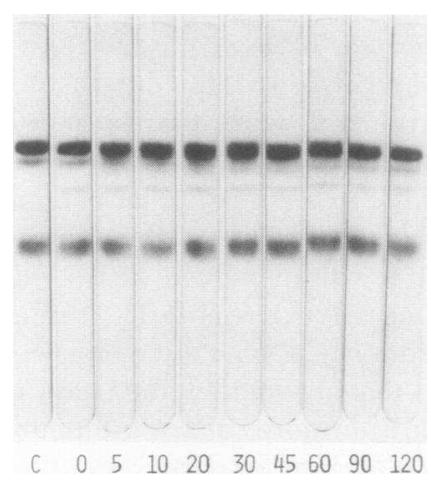

FIGURE 5 SDS-polyacrylamide gel electrophoresis of human protein $C$ after activation by $\alpha$-thrombin. Each sample (100 $\mu \mathrm{l})$ containing $20 \mu \mathrm{g}$ of protein was removed from the reaction mixture corresponding to that shown in Fig. 4, mixed with $1 \mu \mathrm{l}$ of glacial, acetic acid and lyophilized. The lyophilized sample was dissolved in $20 \mu \mathrm{l}$ of $5 \%$ SDS-10\% 2-mercaptoethanol and incubated at $100^{\circ} \mathrm{C}$ for $5 \mathrm{~min}$. Electrophoresis was carried out as described in Methods. The numbers at the bottom of the tubes represent incubation times. 
$\alpha$-thrombin, as monitored by SDS gel electrophoresis and amidase activity measurements, is essentially identical to that observed after the activation of bovine protein $\mathrm{C}$ by $\alpha$-thrombin (5).

As noted earlier, the amidase activity of human activated protein $C$ was readily inhibited by DFP. Covalent binding of this inhibitor to the heavy chain of human activated protein $\mathrm{C}$ was confirmed by using tritiated DFP. In these experiments, human protein $C$ was activated with thrombin and subsequently reacted with $\left[{ }^{3} \mathrm{H}\right] D F P$. The radiolabeled protein was then reduced, S-pyridylethylated, and subjected to gel filtration on a column of Sephadex G-150 (Fig. 6). The two chains readily separated under these conditions and virtually all of the radioactivity was confined to the first peak, which contained the heavy chain. These experiments indicate the binding site for the diisopropyl phosphoryl group in human activated protein $C$ is present in the heavy chain of the enzyme.

Anticoagulant properties of human activated protein $C$. Previous work indicated that bovine activated protein $\mathrm{C}$ markedly prolonged the kaolin-cephalin clotting time of bovine plasma but had no significant effect on the clotting time of human plasma (5). With the availability of purified preparations of human protein $C$, it was of interest to examine whether human protein $\mathrm{C}$ developed anticoagulant activity upon activation, and, if so, its relative effectiveness in human and bovine plasma. The results of these studies indicate that human activated protein $\mathrm{C}$, but not its precursor, exhibited strong anticoagulant activity when human plasma was employed in the assay. In a typical experiment, $200 \mathrm{ng}$ of human activated protein $\mathrm{C}$ increased the kaolin-cephalin clotting time of human plasma from $\cong 45 \mathrm{~s}$ to $>1,200 \mathrm{~s}$, whereas increasing the kaolin-cephalin clotting time of bovine plasma from 35 to $60 \mathrm{~s}$. This anticoagulant activity was completely

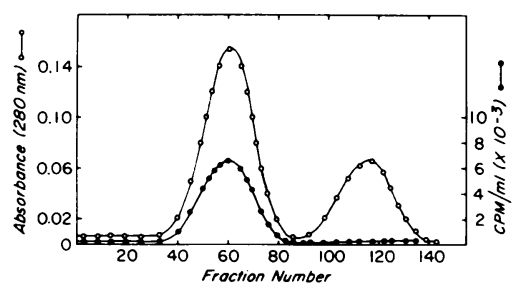

FIGURE 6 Gel filtration of S-pyridylethylated [ ${ }^{3} \mathrm{H}$ ]diisopropylphosphoryl-activated human protein C on a Sephadex G-150 column. $3 \mathrm{mg}$ of protein $\mathrm{C}$ was activated as described in Fig. 4 . After activation, the reaction mixture was treated with $50 \mu \mathrm{C}_{i}$ $\left[{ }^{3} \mathrm{H}\right]-D F P$ and lyophilized. The protein was reduced and S-pyridylethylated as described in Methods and applied to a Sephadex G-150 column $(1.6 \times 95 \mathrm{~cm})$ previously equilibrated with $2.3 \mathrm{M}$ formic acid/3 M urea. Elution was carried carried out with $2.3 \mathrm{M}$ formic acid/3 $\mathrm{M}$ urea and samples were assayed for protein and radioactivity. ( $)$, absorbance; (๑), radioactivity. inhibited by prior treatment of the enzyme with DFP indicating that the anticoagulant activity of the enzyme apparently is totally dependent on its amidase activity.

\section{DISCUSSION}

This work describes a procedure for the isolation of protein $C$ from human plasma. A key step in the separation of protein C from prothrombin, factor X, factor IX, and protein $\mathrm{S}$ was column chromatography on dextran sulfate agarose. This chromatographic matrix was introduced by Pepper and Prowse (31) for the separation of human prothrombin complex and appeared to yield superior resolution in comparison to that observed with heparinagarose under identical conditions. Human protein $\mathrm{C}$ eluted in a symmetrical peak between prothrombin and factor $\mathrm{X}$ from dextran sulfate agarose columns equilibrated at $\mathrm{pH} 6$ in the presence of calcium chloride. Qualitatively similar elution patterns were observed when heparin-agarose was substituted for dextran sulfate agarose under the same conditions, or when dextran sulfate agarose was equilibrated as described by Pepper and Prowse (31). In these chromatographic eluants, however, considerable asymmetry in the elution profiles of protein $\mathrm{C}$ and prothrombin activity were observed.

Human protein $\mathrm{C}$, like the bovine molecule, exists in plasma as a glycoprotein composed of a heavy and a light polypeptide chain held together by a disulfide bond(s). Carbohydrate analysis of human protein $\mathrm{C}$ indicates a higher degree of glycosylation than the bovine protein. The carbohydrate present in human protein $\mathrm{C}$ includes mannose, galactose, glucosamine, and neuraminic acid. In the present study, the heavy and light chains of human protein $\mathrm{C}$ were isolated by gel filtration after reduction and alkylation of the protein, and their amino-terminal sequences were determined.

Although several pieces of evidence point to the striking similarity of protein C. isolated from human and bovine plasma, certain noteworthy differences between the two proteins became apparent during these studies. Perhaps the most significant difference resides in the apparent concentration of this protein in its respective plasma. In this study, 4-8 $\mathrm{mg}$ of protein $\mathrm{C}$ was consistently obtained from 15 liters of human plasma, whereas $20-30 \mathrm{mg}$ of protein $\mathrm{C}$ was isolated from an equivalent amount of bovine plasma (4). Inasmuch as a specific, quantitative assay for human protein $\mathrm{C}$ is not available at present, this difference may stem in part from losses experienced during its isolation. The second significant difference between human and bovine protein $\mathrm{C}$ was obtained from sequence analyses of the heavy and light chains of human protein $C$. With the exception of the amino-terminal aspartic acid residue, the amino-terminal sequence of the heavy chain of 
human protein $\mathrm{C}$ is entirely different from that found in the heavy chain of the bovine protein. In contrast, the first nine residues in the light chain of human protein $\mathrm{C}$ are identical to that found in the light chain of the bovine molecule. Interestingly, the aminoterminal region of the vitamin K-dependent proteins, which contains the $\gamma$-carboxyglutamic acid residues, also contains a highly conserved sequence of Gly-AsnLeu in positions 11-13 (bovine protein $\mathrm{C}$ numbering). The only known exception to this conserved sequence is bovine factor VII, which contains the sequence GlySer-Leu (34) in this position. In this study, none of these residues were observed in this region of the light chain of human protein $\mathrm{C}$ and represents a significant difference between this protein and the other vitamin K-dependent proteins. Whether this structural difference is related to its biological function will require many additional studies.

Like its bovine counterpart, human protein $\mathrm{C}$ exists in plasma as an inactive precursor that is readily converted to a serine enzyme by human $\alpha$-thrombin. As monitored by SDS gel electrophoresis and amidase activity measurements, this activation is essentially identical to that observed during the activation of bovine protein $\mathrm{C}$ by bovine $\alpha$-thrombin. In the activation of the bovine molecule, thrombin cleaves an Arg-Ile bond between residues 14 and 15 in the amino-terminal region of the heavy chain of the protein releasing a very small activation peptide $\left(M_{\mathrm{r}}=1,700\right)$. This results in the formation of activated protein $C$ with a new aminoterminal isoleucine residue in the heavy chain (5). In the activation of human protein $\mathrm{C}$ by thrombin, the formation of a serine amidase activity coincided with the release of a small peptide $\left(M_{r} \cong 1,000\right)$ from the heavy chain. From the sequence analyses of the heavy chain of human protein $\mathrm{C}$, it would appear extremely likely that the bond cleaved during the activation of human protein $\mathrm{C}$ is the Arg-Leu bond between residues 12 and 13 in the amino-terminal region of the heavy chain (Fig. 7). Cleavage of the dodecapeptide $\left(M_{\mathrm{r}}=1,400\right)$ by thrombin would then result in the formation of a new amino-terminal sequence of Leu-Ile-

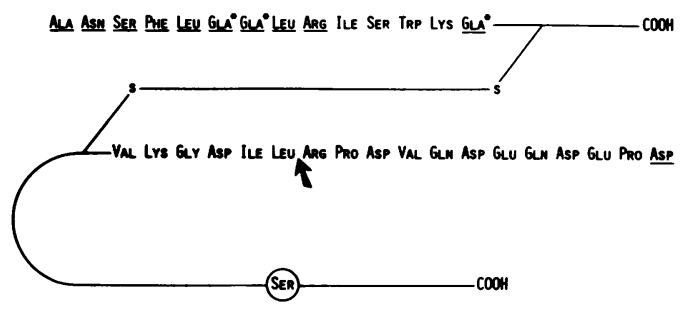

FIgURE 7 Partial structure of human protein C. Residues that are underlined are identical to those found in bovine protein $\mathrm{C}$. $\mathrm{Gla}^{*}(\gamma$-carboxyglutamic acid) shown in positions 6,7 , and 14 of the light chain is tentative. The arrow indicates the probable site of cleavage in the heavy chain of protein $\mathrm{C}$ by thrombin.
Asp-Gly in the heavy chain of human activated protein C. Thus, it seems highly probable that the basic mechanism for the proteolytic activation of human protein $\mathrm{C}$ is similar to that observed in the activation of several other serine proteases including the vitamin K-dependent coagulation factors. Activation of these zymogens involves the cleavage of a peptide bond in the amino-terminal portion of the polypeptide chain containing the active-site serine. During the activation of these proteins, a new amino-terminal isoleucine or valine is generated and this residue presumably forms an ion-pair with the carboxyl group of the aspartic acid adjacent to the active site serine (38). In the case of human protein $\mathrm{C}$, however, the new amino-terminal residue would be leucine. If indeed this residue is shown to be the amino-terminal residue in the heavy chain of human activated protein $C$, it would represent the first example of an amino-terminal leucine residue among the serine proteases characterized to date. Experiments to unambiguously demonstrate this are currently in progress.

Human activated protein $\mathrm{C}$ is a serine amidase with attendant anticoagulant activity. Both the amidolytic and anticoagulant activities of the enzyme are inhibited by DFP, suggesting that both activities are dependent on the active-site serine residue. The apparent species specificity of the anticoagulant activities of both human and bovine activated protein $\mathrm{C}$ is enigmatic and may reflect a highly specific role for protein $\mathrm{C}$ in plasma. The results obtained in this study using highly purified protein preparations corroborate the earlier findings of Marciniak who described a coagulation inhibitor in thrombin-treated human and bovine prothrombin complexes which was highly specific for its homologous plasma $(6,39)$. Clearly, at this point the precise physiological role of protein $C$ in plasma is not known. Bovine activated protein $C$ has been shown to rapidly inactivate factor $\mathrm{V}(5,8)$ and this reaction appears highly specific for the activated form of bovine factor $\mathrm{V} .{ }^{3}$ Whether the proteolytic activity of activated protein $\mathrm{C}$ is specific for the homologous species factor $V_{a}$ as its substrate, as well as the proteolytic range of activated protein $C$, are two important issues that remain to be clarified.

\section{ACKNOWLEDGMENTS}

The author wishes to thank Dr. Earl Davie for his generous support throughout this study, and Dr. William Carter for his assistance in the carbohydrate analyses. The excellent technical assistance of Brad McMullen and Richard Granberg is greatly appreciated. The human plasma employed in these investigations was kindly provided by Hyland Diagnostics Div., Travenol Laboratories, Inc., Costa Mesa, Calif., and the Pacific Northwest Red Cross Blood Program, Portland, Oreg.

\footnotetext{
${ }^{3}$ Canfield, W., M. Nesheim, W. Kisiel, and K. G. Mann. Manuscript in preparation.
} 
This work was supported in part by a Grant-in-Aid from the American Heart Association (77-704) with funds contributed in part by the Montana Heart Association, and in part by Research grant HL 16919 from the National Institutes of Health.

\section{REFERENCES}

1. Kisiel, W. 1978. Isolation and partial characterization of human plasma protein C. Circulation. 58: II-210.

2. Stenflo, J. 1976. A new, vitamin K-dependent protein. Purification from bovine plasma and preliminary characterization. J. Biol. Chem. 251: 355-363.

3. Esmon, C. T., J. Stenflo, J. W. Suttie, and C. M. Jackson. 1976. A new vitamin K-dependent protein. A phospholipid-binding zymogen of a serine esterase. J. Biol. Chem. 251: 3052-3056.

4. Kisiel, W., L. H. Ericsson, and E. W. Davie. 1976. Proteolytic activation of protein $C$ from bovine plasma. Biochemistry. 15: 4893-4900.

5. Kisiel, W., W. M. Canfield, L. H. Ericsson, and E. W. Davie. 1977. Anticoagulant properties of bovine plasma protein $\mathrm{C}$ following activation by thrombin. Biochemistry. 16: 5824-5831.

6. Marciniak, E. 1970. Coagulation inhibitor elicited by thrombin. Science (Wash. D. C.). 170: 452-453.

7. Wright, I. S. 1959. Nomenclature of blood clotting factors. JAMA (J. Am. Med. Assoc.). 170: 325-328.

8. Canfield, W., M. Nesheim, W. Kisiel, and K. G. Mann. 1978. Proteolytic inactivation of bovine factor $\mathrm{Va}$ by bovine activated protein C. Circulation. 58: II-210.

9. Kurachi, K., G. Schmer, M. A. Hermodson, D. C. Teller, and E. W. Davie. 1976. Characterization of human, bovine, and horse antithrombin II. Biochemistry. 15: 368-373.

10. Bell, W. N., and H. G. Alton. 1954. A brain extract as a substitute for platelet suspensions in the thromboplastin generation test. Nature (Lond.). 174: 880-881.

11. Kisiel, W., M. A. Hermodson, and E. W. Davie. 1976. Factor X activating enzyme from Russell's viper venom: Isolation and characterization. Biochemistry. 15: 49014906.

12. Lundblad, R. L., L. C. Uhteg, C. N. Vogel, H. S. Kingdon, and K. G. Mann. 1975. Preparation and partial characterization of two forms of bovine thrombin. Biochem. Biophys. Res. Commun. 66: 482-489.

13. Kisiel, W., and D. J. Hanahan. 1973. The action of factor $\mathrm{Xa}$, thrombin and trypsin on human factor II. Biochim. Biophys. Acta. 329: 221-232.

14. DiScipio, R. G., M. A. Hermodson, and E. W. Davie. 1977. Activation of human factor X (Stuart factor) by a protease from Russell's viper venom. Biochemistry. 16: 5253-5260.

15. Cuatrecasas, P. 1970. Protein purification by affinity chromatography. J. Biol. Chem. 245: 3059-3065.

16. Edelhoch, H. 1967. Spectroscopic determination of tryptophan and tyrosine in proteins. Biochemistry. 6: 19481954.

17. Fenton, J. W., M. J. Fasco, A. B. Stackrow, D. L. Aronson, A. M. Young, and J. S. Finlayson. 1977. Human thrombins: production, evaluation and properties of $\alpha$-thrombin. $J$. Biol. Chem. 252: 3587-3598.

18. Moore, S., and W. H. Stein. 1963. Chromatographic determination of amino acids by the use of automatic recording equipment. Methods Enzymol. 6: 819-831.

19. Spackman, D. H., W. H. Stein, and S. Moore. 1958. Automatic recording apparatus for use in the chromatography of amino acids. Anal. Chem. 30: 1190-1206.
20. Hugli, T. E., and S. Moore. 1972. Determination of the tryptophan content of proteins by ion exchange chromatography of alkaline hydrolysates. J. Biol. Chem. 247: 2828-2834.

21. Hirs, C. H. W. 1967. Determination of cystine as cysteic acid. Methods Enzymol. 11: 59-62.

22. Warren, L. 1959. The thiobarbituric acid assay of sialic acid. J. Biol. Chem. 234: 1971-1975.

23. Yang, H. J., and S. I. Hakomori. 1971. A sphingolipid having a novel type of ceramide and lacto- $N$-fucopentose III. J. Biol. Chem. 246: 1192-1200.

24. Edman, P., and G. Begg. 1967. A protein sequenator Eur. J. Biochem. 1: 80-91.

25. Bridgen, P. J., G. A. M. Cross, and J. Bridgen. 1976 $\mathrm{N}$-terminal amino acid sequences of variant-specific surface antigens from Trypanosoma brucei. Nature (Lond.). 263: 613-614.

26. Ericsson, L. H., R. D. Wade, J. Gagnon, R. M. McDonald, R. Granberg, and K. A. Walsh. 1977. High performance liquid chromatography of Pth-amino acids using a Durrum D-500 analyzer. In Solid Phase Methods in Protein Sequence Analysis. A. Previero and M. A. Coletti-Previero, editors. Elsevier, Holland. 1: 137-142.

27. Bachmann, F., F. Duckert, and F. Koller. 1958. The StuartPrower factor assay and its clinical significance. Thromb. Diath. Haemorrh. 2: 24-38.

28. Hjort, P., S. I. Rapaport, and P. A. Owen. 1955. A simple, specific one-stage prothrombin assay using Russell's viper venom in cephalin suspensions. J. Lab. Clin. Med. 46: 89-97.

29. Fujikawa, K., A. R. Thompson, M. E. Legaz, R. G. Meyer, and E. W. Davie. 1973. Isolation and characterization of bovine factor IX (Christmas factor). Biochemistry. 12: 4938-4945.

30. Nemerson, Y., and L. P. Clyne. 1974. An assay for coagulation factor VII using factor VII-depleted bovine plasma. J. Lab. Clin. Med. 83: 301-303.

31. Pepper, D. S., and C. Prowse. 1977. Chromatography of human prothrombin complex on dextran sulfate agarose. Thromb. Res. 11: 687-692.

32. Friedman, M., L. H. Krull, and J. F. Cavins. 1970. The chromatographic determination of cystine and cysteine residues in proteins as $\mathbf{S}-\boldsymbol{\beta}$-(4-pyridylethyl) cysteine. J. Biol. Chem. 245: 3868-3881.

33. Fujikawa, K., K. Titani, and E. W. Davie. 1975. Activation of bovine factor $X$ (Stuart factor): conversion of factor $\mathrm{X}_{\mathrm{a} \alpha}$ to factor $\mathrm{X}_{\mathrm{a} \beta}$. Proc. Natl. Acad. Sci. U. S. A. 72: 33593363.

34. DiScipio, R. G., M. A. Hermodson, S. G. Yates, and E. W. Davie. 1977. A comparison of human prothrombin, factor IX (Christmas factor), factor X (Stuart factor), and protein S. Biochemistry. 16: 698-706.

35. DiScipio, R. G., and E. W. Davie. 1979. Characterization of protein $S$, a $\gamma$-carboxyglutamic acid containing protein from bovine and human plasma. Biochemistry. 18: 899904.

36. Fernlund, P., J. Stenflo, and A. Tufvesson. 1978. Bovine protein $\mathrm{C}$ : amino acid sequence of the light chain. Proc. Natl. Acad. Sci. U. S. A. 75: 5889-5892.

37. Nesheim, M. E., F. G. Prendergast, and K. G. Mann. 1979. Interactions of a fluorescent active-site-directed inhibitor of thrombin: dansyl-arginine $N$-(3-ethyl-1,5-pentanediyl)amide. Biochemistry. 18: 996-1003.

38. Kraut, J. 1977. Serine proteases: structure and mechanism of catalysis. Annu. Rev. Biochem. 46: 331-358.

39. Marciniak, E. 1972. Inhibitor of human blood coagulation elicited by thrombin. J. Lab. Clin. Med. 79: 924-934. 